\title{
PENGARUH METODE PERMAINAN TERHADAP HASIL BELAJAR PERKALIAN PADA MATA PELAJARAN MATEMATIKA KELAS III SDN 319 LOKAJAHA KABUPATEN BULUKUMBA
}

\author{
Amril, Ernawati \\ FKIP Universitas Muhammadiyah Makassar \\ email: amrilbondan@yahoo.com
}

\begin{abstract}
Abstrak: Jenis penelitian ini adalah penelitian eksperimen yang melibatkan satu kelas sebagai kelas eksperimen, dengan tujuan untuk mengetahui pengaruh penerapan metode permainan terhadap hasil belajar perkalian pada mata pelajaran matematika kelas III SD Negeri 319 Lokajaha Kabupaten Bulukumba tahun ajaran 2017/2018. Sedangkan penelitian ini mengacu pada criteria hasil pembelajaran yaitu ketuntasan belajar individu. Penelitian ini mengacu pada hasil belajar siswa terhadap pembelajaran matematika. desain penelitian yang digunakan adalah one group pretest-posttest design, yaitu penelitian yang hanya menggunakan satu kelas kontrol tanpa ada kelas pembanding. Penelitian dilaksanakan selama 6 kali pertemuan. Teknik pengumpulan data yang dilakukan adalah tes awal dan tes akhir. Lembar observasi untuk mengamati kemampuan hasil belajar perkalian siswa pada mata pelajaran matematika menggunakan metode permainan. Hasil penelitian menunjukkan bahwa: (1) skor rata-rata tes hasil belajar matematika sebelum diterapkannya metode permainan (pretest) adalah 62,56. Dan berada pada kategori sangat rendah dengan standar deviasi 3,81 dimana skor terendah diperoleh adalah 33,00 dan skor tertinggi adalah 93,00 dari skor ideal 100. Dari hasil tersebut diperoleh bahwa 5 siswa atau 17,86\% mencapai ketuntasan individu sementara 23 siswa atau 82,14 \% tidak mencapai ketuntasan individu dan ini berarti bahwa ketuntasan secara klasikal tidak tercapai dan setelah diterapkannya model pembelajaran tersebut (posttest) diperoleh skor rata-rata tes hasil belajar siswa adalah 80,93 dan berada pada kategori tinggi dengan standar deviasi 4, 53 dimana skor terendah diperoleh 62,00 dan skor tertinggi 100 dari skor ideal 100. Dari hasil tersebut bahwa 22 siswa atau 78,57\% mencapai ketuntasan individu, sementara 6 siswa atau 21,43\% tidak mencapai ketuntasan individu dan ini berarti bahwa ketuntasan secara klasikal dapat tercapai. Berdasarkan hasil penelitian, maka metode permainan berpengaruh dan dapat diterapkan terhadap hasil belajar perkalian pada mata pelajaran matematika kelas III SD Negeri 319 Lokajaha Kabupaten Bulukumba.
\end{abstract}

Kata kunci : metode permainan, matematika, hasil belajar 


\section{PENDAHULUAN}

Pendidikan adalah usaha sadar yang dilakukan oleh seorang pendidik terhadap peserta didik dimana tujuan dari usaha tersebut adalah untuk mengembangkan potensi-potensi yang ada pada peserta didik dan bertanggung jawab atas perkembangan moral peserta didik. Seperti yang terdapat dalam UU 20/2003 tentang Sistem Pendidikan Nasional, Pasal 3, disebutkan:

"Pendidikan nasional berfungsi mengembangkan kemampuan dan membentuk watak serta peradaban bangsa yang bermartabat dalam rangka mencerdaskan kehidupan bangsa, bertujuan untuk berkembangnya potensi peserta didik agar menjadi manusia yang beriman dan bertakwa kepada Tuhan Yang Maha Esa, berakhlak mulia, sehat, berilmu, cakap, kreatif, mandiri, dan menjadi warga negara yang demokratis serta bertanggung jawab."

Berdasarkan pernyataan di atas, dapat diketahui bahwa fungsi dari pendidikan nasional di atas adalah untuk membentuk manusia yang cakap, kreatif dan mandiri. Untuk menghasilkan manusia -manusia yang cakap, kreatif dan mandiri dibutuhkan suatu pembelajaran yang berkualitas. Salah satu pilar yang paling penting dalam kesuksesan pembelajaran adalah seorang guru. Guru yang baik tidak hanya sekedar mentransfer ilmu kepada seluruh siswanya, tapi guru juga harus memperhatikan perkembangan kreativitas berpikir siswa. Sehingga siswa tidak hanya sekedar tau tetapi mengerti bagaimana mereka tau.

Pembelajaran yang baik adalah pembelajaran yang menyenangkan dan penuh dengan pengalaman belajar untuk siswa.

Dunia pendidikan terus berkembang menuju kearah yang lebih baik dan modern. Perubahan-perubahan dalam dunia pendidikan biasanya diikuti oleh kemajuan ilmu pengetahuan dan teknologi, karena kemajuan tersebut tentu saja harus didukung oleh setiap pelaku pendidikan agar pendidikan dapat diselaraskan sesuai dengan kebutuhan dan perkembangan zaman. Untuk itu, guru selaku pelaku pendidikan harus memberikan wawasan kepada anak didiknya agar turut serta membangun iklim pendidikan.

Dalam hal ini dibutuhkan suatu metode pembelajaran yang melibatkan peserta didik secara aktif, sehingga siswa akan menikmati proses pembelajaran yang dilakukan. Metode pembelajaran yang biasanya kita lakukan adalah dengan metode menghafal, namun metode ini terbatas bagi peserta didik yang mempunyai tingkat intelektual yang rendah. Metode menghafal di luar kepala tidak akan bisa menggantikan aktifitas langsung yang membuat seseorang mengalami dan mencerna informasi baru.

Matematika adalah suatu pelajaran yang pada saat ini masih menjadi pelajaran yang paling menakutkan bagi siswa. Banyak siswa yang merasa bosan mempelajari matematika, karena metode yang dipakai guru dalam mengajar sangat monoton. Guru beranggapan bahwa jawaban yang paling benar adalah jawaban yang sama persis dengan yang diajarkannya. Padahal matematika mempunyai banyak alternatif cara penyelesaian untuk menyelesaikan satu soal dengan hasil yang sama tetapi dengan jalan yang berbeda. Menurut Kurikulum Tingkat Satuan Pendidikan Dinas Pendidikan (2006 : 9), Sejalan dengan tujuan dari mata pelajaran matematika adalah : 1) 
Memahami konsep matematika, menjelaskan keterkaitan antar konsep dan mengaplikasikan konsep atau algoritma, secara luwes, akurat, efisien, dan tepat, dalam pemecahan masalah; 2) Menggunakan penalaran pada pola dan sifat, melakukan manipulasi matematika dalam membuat generalisasi, menyusun bukti, atau menjelaskan gagasan dalam pernyataan matematika; 3) Memecahkan masalah yang meliputi kemampuan memahami masalah, merancang model matematika, menyelesaikan model dan menafsirkan solusi yang diperoleh; 4) Mengkomunikasikan gagasan dengan simbol, tabel, diagram, atau media lain untuk menjelaskan keadaan masalah; 5) memiliki sikap menghargai kegunaan matematika dalam kehidupan, yaitu memiliki rasa ingin tahu, perhatian, dan minat dalam mempelajari matematika, serta sikap ulet dan percaya diri dalam pemecahan masalah.

Berdasarkan tujuan dari mata pelajaran matematika, maka berbagai macam cara ditempuh oleh pelaku pendidikan maupun orang yang peduli terhadap pendidikan baik yang bersifat formal maupun nonformal untuk terus menciptakan metode pembelajaran yang kreatif, inovatif serta menarik minat anak didik untuk selalu mencintai dan menyukai belajar matematika, sebab belajar matematika menurut sebagian besar anak-anak merupakan pembelajaran yang sangat sulit dan memusingkan. Meski banyak yang beranggapan bahwa matematika sulit, namun harus dipelajari. Karena matematika merupakan sarana yang sangat penting untuk memecahkan masalah dalam kehidupan sehari-hari.

Banyak metode pembelajaran yang berkembang dewasa ini yang telah diciptakan untuk memudahkan anak didik untuk menyukai matematika diantaranya adalah metode permainan.

Menurut Dienes (dalam Ruseffendi, 1992: 187) menyatakan bahwa "Metode permainan adalah metode mengajar dimana cara penyajian materi dengan permainan. Sehingga dengan permainan tanpa disadari oleh anak/peserta didik bahwa mereka telah disuguhi pelajaran matematika". Selain itu, untuk lebih merangsang minat anakanak belajar matematika adalah dengan menggunakan bahasa yang sederhana yang mudah dimengerti, sehingga mereka lebih mudah belajar dan menerima penjelasan dari pendidiknya maupun dari orang tuanya. Metode permainan (games), terkenal dengan berbagai sebutan antara lain pemanasan (ice-breaker) atau penyegaran (energizer). Arti harfiah ice-breaker adalah 'pemecah es'. Jadi, arti pemanasan dalam proses belajar adalah pemecah situasi kebekuan fikiran atau fisik peserta. Permainan juga dimaksudkan untuk membangun suasana belajar yang dinamis, penuh semangat, dan antusiasme.

Karakteristik permainan adalah menciptakan suasana belajar yang menyenangkan (fun) serta serius tapi santai (sersan). Permainan digunakan untuk penciptaan suasana belajar dari pasif ke aktif, dari kaku menjadi gerak (akrab) dan dari jenuh menjadi riang (segar)

Akan tetapi, dalam kegiatan belajar mengajar (KBM) sebelum mengenal lebih jauh tentang perkalian sebaiknya guru mengetahui terlebih dahulu kemampuan anak didiknya. Sebab, pada perkalian ini anak didik minimal haruslah paham tentang dasar matematika yaitu penjumlahan dan pengurangan, sebab arti dari perkalian adalah 
penjumlahan berulang. Setelah paham betul kemampuan anak didik tentang penjumlahan dan pengurangan, barulah guru dapat menerapkan perkalian.

Sesuai dengan uraian diatas, maka kami mencoba menerapkan metode permainan dengan maksud supaya setiap individu pelajar memiliki kemampuan operasi hitung perkalian yang mudah dan cepat serta mampu menghitung operasi hitung perkalian dengan menggunakan daya nalar.

Penelitian kami tujukan pada SD Pertiwi Makassar dengan judul "Pengaruh Metode Permainan Terhadap Hasil Belajar Perkalian Pada Mata Pelajaran Matematika Siswa Kelas III SDN 319 Lokajaha Kabupaten Bulukumba".

\section{METODE}

Jenis penelitian yang dilakukan adalah jenis penelitian eksperimen. Penelitian eksperimen merupakan penelitian sistematis, logis dan teliti untuk melakukan kontrol terhadap kondisi, yang bertujuan mengungkapkan Pengaruh Metode permainan Terhadap Hasil Belajar Perkalian Pada Mata Pelajaran Matematika Siswa Kelas III SDN 319 Lokajaha Kabupaten Bulukumba. Dalam penelitian ini digunakan desain praeksperimen karena hanya melibatkan satu kelas saja sebagai kelas eksperimen yang dilaksanakan tanpa adanya kelompok.

Desain eksperimen yang digunakan dalam penelitian ini adalah One Group pre-test dan post-test Desain (satu kelompok pretest-postest). Pre-test digunakan untuk mengetahui hasil belajar perkalian matematika sebelum diberi perlakuan. Dengan demikian hasil belajar perkalian siswa dapat diketahui, karena dapat dibandingkan dengan keadaan sebelum diberi perlakuan. Sedangkan post-test digunakan untuk mengetahui hasil belajar perkalian matematika siswa setelah diberi perlakuan.

Dalam penelitian ini terdapat dua variabel yang diamati, yaitu variable bebas dan variabel terikat. Variable bebas dalam penelitian ini adalah Metode permainan dengan menggunakan trik mathmagic sebagai variabel bebas (dependen), sedangkan variabel terikat adalah hasil belajar perkalian siswa sebagai variabel terikat (independen). Dalam penelitian ini populasi yang digunakan adalah seluruh siswa kelas III SDN 319 Lokajaha Kabupaten Bulukumba. Dalam penelitian ini peneliti menggunakan samping jenuh, yaitu teknik sampling dimana semua populasi dijadikan sebagai sampel. Dalam penelitian ini sampel yang digunakan yaitu kelas III yang terdiri dari 28 siswa, 15 perempuan dan 13 laki-laki.

Instrument yang digunakan dalam penelitian ini adalah tes kemampuan belajar, lembar observasi aktivitas murid. Teknik pengumpulan data yang digunakan dalam penelitian ini adalah tes awal dan tes akhir. Analisis data penelitian dimaksudkan untuk menganalisis data hasil tes penelitian berkaitan dengan metode pembelajaran Mind Mapping yang telah diterapkan, teknik analisis data yang digunakan adalah analisis deskriftif dan analisis statistik inferensial. 
Hipotesis yang diuji dalam penelitian ini adalah sebagai berikut:

$\mathrm{H}_{0}$ : Tidak ada pengaruh yang signifikan antara penggunaan Metode permainan terhadap Hasil Belajar Perkalian Pada Mata Pelajaran Matematika Siswa Kelas III SDN 319 Lokajaha Kabupaten Bulukumba.

$\mathrm{H}_{\mathrm{a}}$ : Ada pengaruh yang signifikan antara penggunaan Metode permainan terhadap Hasil Belajar Perkalian Pada Mata Pelajaran Matematika Siswa Kelas III SDN 319 Lokajaha Kabupaten Bulukumba.

\section{HASIL DAN PEMBAHASAN}

Sebagaimana telah diuraikan sebelumnya bahwa tujuan penelitian ini adalah untuk mengetahui pengaruh metode permainan terhadap hasil belajar perkalian pada mata pelajaran matematika SD Negeri 319 Lokajaha Kabupaten Bulukumba. Untuk mengetahui pengaruh metode permainan terhadap hasil belajar perkalian pada mata pelajaran matematika SD Negeri 319 Lokajaha Kabupaten Bulukumba, dilakukan prosedur penelitian eksperimen dan analisis data hasil penelitian dengan menggunakan teknik analisis deskriptif dan teknik analisis inferensial.

\section{Langkah-langkah Metode Permainan}

Hasil metode permainan diperoleh dari serangkaian aktivitas seperti yang telah diutarakan didepan. Desain pembelajaran tidak bersifat mengikat/kaku sebagai urutan pembelajaran. Desain awal yang telah direvisi dan sengaja dihubungkan kembali dengan telaah literatur terkait untuk memperkuat konstruksi desain dapat dilihat pada tabel 1 .

\section{Hasil Belajar Matematika Sebelum dan Sesudah Perlakuan}

Hasil analisis secara deskriptif dari skor pretest dan posttest digunakan untuk melihat skor rata-rata dan deviasi estándar. Tabel 2 menunjukkan statistik deskriptif.

\section{Tabel 1 Langkah-langkah Metode Permainan}

- Guru menentukan topik atau materi permainan yang akan digunakan dalam pembelajaran.

- Guru menyiapkan alat dan bahan yang diperlukan.

- Guru menyusun petunjuk atau langkah-langkah pelaksanaan permainan.

- Guru menjelaskan maksud dan tujuan serta aturan dalam permainan.

- Siswa dibagi atas individu atau kelompok.

- Siswa melakukan kegiatan permainan yang dipimpin oleh guru.

- Siswa berhenti melakukan permainan dan melaporkan hasil dari permainan. 
- Guru memberikan kesimpulan tentang pengertian atau konsep yang dimaksud dalam tujuan tersebut.

\section{Tabel 2 Deskripsi Skor}

Skor Pre-test

Statistik

Skor ideal

Skor terendah

Skor tertinggi

Rentang skor

Rata-rata skor

Standar deviasi
Nilai
100
33
93
60
62,56
3,81

\section{Skor Posttest}

$\begin{array}{ll}\text { Statistik } & \text { Nilai } \\ \text { Skor ideal } & 100 \\ \text { Skor terendah } & 62 \\ \text { Skor tertinggi } & 100 \\ \text { Rentang skor } & 38 \\ \text { Rata-rata skor } & 80,93 \\ \text { Standar deviasi } & 4,53\end{array}$

Dalam penggunaan statistik inferensial, peneliti menggunakan teknik statistik $\mathrm{t}$ (uji-t). Berdasarkan perhitungan diperoleh nilai thitung sebesar 11,86 dan tabel sebesar 3,690 dengan taraf signifikansi 0,05. Hasil pengujian bahwa thitung ternyata memenuhi kriteria pengujian thitung $>$ ttabel. Dengan demikian Ho ditolak dan $\mathrm{H}_{1}$ di terima. Sehingga dapat disimpulkan bahwa terdapat perbedaan hasil belajar Matematika yang signifikan antara murid yang diberikan perlakuan dengan yang tidak diberikan perlakuan metode permainan.

\section{PEMBAHASAN}

Timbulnya keinginan seseorang untuk melakukan penelitian berawal dari sebuah masalah dan masalah itu terjadi di SDN 319 Lokajaha Kabupaten Bulukumba. Masalah yang terjadi di SDN 319 Lokajaha Kabupaten Bulukumba yaitu metode perkalian yang di gunakan oleh guru adalah metode yang sangat lazim yang membuat siswa cepat bosan dalam mempelajari matematika khususnya materi perkalian dalam hal ini kurang Nampak kreativitas guru dalam menerapkan metode perkalian sehingga kurang cepat bahkan tidak bisa di serap oleh anak didik. Maka dari itu peneliti merasa harus memberikan sebuah perlakuan disekolah tersebut dengan menggunakan sebuah metode pembelajaran yang cocok diterapkan dan 
mampu membuat anak didik tertarik belajar matematika dengan semangat dan menyenangkan, selain itu peneliti juga ingin megetahui sejauh mana pengaruh perlakuan yang diberikan kepada responden agar masalah yang ada bisa teratasi sehingga tujuan pendidikan yang terdapat pada Undang -undang Nomor 20 tahun 2003 tentang Sistem Pendidikan Nasional bertujuan untuk mengembangkan potensi peserta didik agar menjadi manusia yang beriman dan bertaqwa kepada Tuhan Yaang Maha Esa, berakhlak mulia, sehat, berilmu, cakap, kreatif, mandiri, dan menjadi warga Negara yang demokratis serta bertanggung jawab (Sani dan Muhammad Kadri, 2016:5).

Proses pembelajaran memegang peranan yang sangat penting dalam menghasilkan atau menciptakan kualitas lulusan pendidikan. Oleh karena itu, hal utama yang seyogyanya mendapatkan perhatian lebih serius adalah menciptakan proses pembelajaran yang berkualitas. Untuk menghasilkan proses pembelajaran yang berkualitas sangat ditentukan oleh guru sebagai pengajar yang profesional dengan kualifikasi sebagaimana yang diamanahkan oleh Undang-Undang Nomor 14 Tahun 2005 Tentang Guru dan Dosen, penggunaan metode pengajaran yang menarik dan bervariasi, perilaku belajar peserta didik yang positif, kondisi dan suasana belajar yang kondusif untuk belajar, dan penggunaan media pembelajaran yang tepat dalam mendukung proses belajar itu sendiri.

Penjelasan berupa gambar sederhana di papan tulis serta keterangan yang bersifat verbal belum dapat menghasilkan pemahaman yang komprehensif sehingga perlu adanya metode pembelajaran yang lebih kreatif dan menyenangkan anak didik. Metode pembelajaran merupakan unsur yang sangat penting dalam proses pembelajaran. Pemilihan metode mengajar tertentu akan mempengaruhi kondisi pembelajaran yang diterapkan. Pemakaian metode pembelajaran dalam proses pembelajaran dapat membangkitkan motivasi dan rangsangan kegiatan belajar. Adapun metode pembelajaran yang digunakan yaitu metode Permainan yang mana peneliti menggunakan beberapa trik tertentu yang sangat menarik dan menyenangkan sehingga murid dengan mudah memahami pembelajaran yang diterapkan.

Penggunaan metode sangat membantu seorang guru dalam mengajar. Sebagaimana tujuan metode permainan yaitu untuk meningkatkan kreatifitas anak didik serta untuk menumbuhkan semangat belajar serta menarik perhatian anak sehingga kelas menjadi hidup

Metode permainandiharapkan dapat membantu meningkatkan pemahaman sekaligus hasil belajar murid pada mata pelajaran Matematika. Melalui penggunaan Metode permainan para murid kelas III SDN 319 Lokajaha Kabupaten Bulukumba dapat meningkatkan hasil belajar mereka melalui instrumen berupa sejumlah pertanyaan dalam bentuk pretest, postTest.

Hasil belajar adalah hasil yang diperoleh seseorang setelah melewati berbagai macam tantangan berdasarkan ruang lingkup masalah yang dihadapinya, besarnya hasil belajar yang diperoleh seseorang tergantung dari seberapa besar dan seberapa kuat dia untuk memperolehnya 
Menurut Wingkel (Takdir, 2015:11) hasil belajar adalah perubahan yang mengakibatkan manusia berubah dalam sikap dan tingkah lakunya, menggolongkan kemampuan-kemampuan yang menyebabkan perubahan tersebut menjadi kemampuan kognitif yang meliputi pengetahuan dan pemahaman, kemampuan sensorik motorik yang meliputi keterampilan melakuakan rangkaian gerak badan dalam urutan tertentu, dan kemampuan dinamik afektif meliputi sikap dan nilai yang meresapi perilaku dan tindakan.

Kline (1973: 145) menyatakan bahwa "Matematika bukanlah pengetahuan yang dapat menjadi sempurna untuk dirinya sendiri, tetapi matematika terutama untuk membantu orang memahami dan mengatasi masalah Matematika sosial, ekonomi dan alam. Ini tumbuh dan berkembang karena proses berpikir, oleh karena itu, logika adalah dasar untuk pembentukan matematika."

Berdasarkan hasil penelitian dan analisa data mengenai perbandingan nilai statistik menunjukkan bahwa jumlah sampel 28 orang, nilai pretest untuk nilai terendah adalah 33 ( tiga puluh tiga ) dan nilai tertinggi 93 ( sembilan puluh tiga). Nilai posttest untuk nilai terendah 62 (enam puluh dua) dan nilai tertinggi 100 (seratus), rata-rata pretest 62,56 dan rata-rata posttest 80,93 serta standar deviasi pretest 3,81 sedangkan deviasi posttess 4,53.

Perbandingan kategori hasil belajar menunjukkan bahwa persentase kategori nilai murid pada proses pembelajaran perkalian matematika dengan menggunakan metode Permainan (1) kategori sangat rendah (0-54), persentasi pada pretest sebanyak 42,86\% dan persentasi pada posttest sebanyak 0\%;(2) kategori rendah (5564), persentasi pada pretest sebanyak $10,71 \%$ dan pada posttest sebanyak $14,28 \%$; (3) kategori sedang (65-79), persentasi pada pretest sebanyak $28,57 \%$ dan pada posttest sebanyak 7,24\%; (4) kategori tinggi (80-89) persentasi pada pretest sebanyak $3,57 \%$ dan pada posttest sebanyak 46,44\%; dan (5) kategori sangat tinggi (90-100) persentasi pada pretest sebanyak 14,29\% dan pada posttest sebanyak 32,14\%.

Perbandingan tingkat ketuntasan atas menunjukkan bahwa persentase kategori ketuntasan hasil belajar murid pada proses pembelajaran matematika dengan metode permainan diterapkan ; (1) murid yang berada pada kategori tidak tuntas pada pretest sebanyak $82,14 \%$ dan murid yang tuntas sebanyak $317,86 \%$ dan (2) murid yang berada pada kategori tidak tuntas pada post test sebanyak $21,43 \%$ dan murid yang tuntas pada posttest sebanyak 78,57\%.

Dan juga berdasarkan hasil yang diperoleh dari uji-t diperoleh nilai thitung sebesar 11.86 dan tabel sebesar 3,690 dengan taraf signifikansi 0,05. Hasil pengujian bahwa thitung ternyata memenuhi kriteria pengujian thitung $>t_{\text {tabel. }}$. Dengan demikian Ho ditolak dan $\mathrm{H}_{1}$ di terima. Sehingga dapat disimpulkan bahwa terdapat perbedaan dan pengaruh hasil belajar perkalian matematika yang signifikan antara murid yang diberikan perlakuan dengan yang tidak diberikan perlakuan metode permainan.

\section{PENUTUP}

Berdasarkan hasil penelitian di kelas III SDN Lokajaha Kabupaten Bulukumbayang mengkaji tentang pengunaan metode permainandan hasil belajar siswa, maka disimpulkan bahwa terdapat pengaruh yang signifikan penggunaan metode 
permainan terhadap hasil belajar perkalian matematika kelas III SDN 319 Lokajaha Kabupaten Bulukumba, sehingga metode ini layak digunakan untuk meningkatkan hasil belajar perkalian matematika.

\section{UCAPAN TERIMA KASIH}

Ucapan terima kasih kepada Rektor Universitas Muhammadiyah Makassar dan Kepala Sekolah SDN 319 Lokajaha Kabupaten Bulukumba yang telah memberikan izin untuk melakukan penelitian ini. Peneliti juga mengucapkan terima kasih kepada Drs. H. Muh Yamin Wahab, M. Pd dan Kristiawati, M. Pd yang telah membimbing dan memberi masukan serta saran untuk melakukan penelitian ini.

\section{DAFTAR PUSTAKA}

Abdurahman. 2012. Pendekatan PAILKEM untuk meningkatkan Hasil Belajar. Bandung: Andira

Adjie, N. dan Maulana. 20016. Pemecahan Masalah Matematika. Bandung: UPI Press

Ediaty. 2008. Kelebihan dan Kekurangan Mathmagic. Jakarta: Mizan

Enik, Chaerul Umah. 2013. Peningkatan hasil belajar operasi hitung bilangan bulat melalui MTB pada siswa kelas IV SD Muhammadiyah 1 Sidoarjo. Jurnal Mimbar Pendidikan Indonesia, 1(2): 40-48

Handojo. 2007. Cara Pandang Baru Belajar Matematika. Bandung: Rosdakarya

Harini, L.P.I., Nilakusmawati, D.P.E., 2014. Kajian efektivitas penerapan metode ringkas dalam perkalian susun. Jurnal Matematika, 4 (2): 111 - 129

Harlina. 2009. Pengaruh Pengelolaan Kelas Terhadap Hasil Belajar. Jakarta: Bumi Aksara

Leonard. 2013. Peran kemampuan berpikir kritis terhadap prestasi belajar matematika. Jurnal Mimbar Pendidikan Indonesia, 1(2): 61-71

Maman \& Sarjaya. 2014. Metode tutor sebaya untuk meningkatkan hasil belajar matematika pada materi pengolahan data. Jurnal Formatif, 4(1): 71-79

Muhammad, As'adi. 2009. Menghidupkan Otak Kanan Pada Anak Anda. Yogyakarta: Power Books

Ruseffendi, E.T, dkk. 1992. Pendidikan Matematika. Jakarta: Depdikbud

Setyono. 2007. Matchmagic Untuk Pembelajaran Menyenangkan. Jakarta: Yudhistira 
Suminah. 2009. Peningkatan Hasil Belajar Siswa dengan menerapkan metode buzz grup pada Mata Pembelajaran IPS kelas IV SD. Skripsi Universitas Negeri Makassar.

Surakhmad, Winarno. 1982. Pengantar Interaksi dalam Belajar, Dasar dan Teknik Metode Pengajaran. Bandung: Tarsito

Suwangsih. 2006. Model Pembelajaran Matematika. Bandung: UPI Press

Syafik, Abu. 2012. Permainan matematika sebagai metode alternatif dalam pembelajaran matematika pada siswa kelas 1 sekolah dasar. Jurnal LIMITPendidikan Matematika. 1 (2): 21-36

Yunus. 2005. Tantangan Pendidikan Abad 21. Jakarta: Grafindo

Undang-Undang No 20 Tahun 2003 Tentang Sistem Pendidikan Nasional

http://tips-belajar internet.blogspot.com/2009/08/hasil-belajar-matematika.html. diakses tanggal 02 Mei 2017

http://deparisiska.blogspot.com/2011/05/efektivitas-metode-mathmagicdalam_16.html diakses tanggal 02 Mei 2017. 
